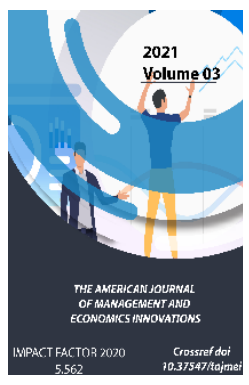

\title{
Organization Of Accounting In Organizations Of The Non- Governmental Education System
}

\author{
Aybek Nazarbayevich Abdullayev \\ PhD Student, Tashkent Institute Of Finance, Uzbekistan
}

Journal Website:

http://theamericanjour

nals.com/index.php/taj

mei

Copyright: Original

content from this work

may be used under the

terms of the creative

commons attributes

4.0 licence.

\section{ABSTRACT}

The article discusses the procedure, stages of organization of accounting in business entities providing non-governmental educational services and the parties involved in this process. The article also examines the responsibilities of the participants in the organization of the account, the organizational, technical and methodological aspects of this process.

\section{KEYWORDS}

Accounting policy, non-governmental educational services, financial reporting, organizational and legal form of ownership, taxation system.

\section{INTRODUCTION}

Public authorities and administration in accordance with Article 6 of the Law of the Republic of Uzbekistan "On Accounting"; the subjects of accounting are legal entities registered in the Republic of Uzbekistan, their subsidiaries, representative offices, branches and other structural units located in the territory of the Republic of Uzbekistan and abroad. The organization of accounting and reporting should be carried out by the heads of the accounting entity. The reason is that all business entities, regardless of their organizational, legal and form of ownership, face accounting in the process of carrying out certain activities. Of course, in order to organize and maintain accounting, an accounting policy must first be developed and approved. The current regulations do not contain provisions that make it mandatory for business entities to have an accounting policy. However, given what accounting policies are and for what purpose they are formulated, we can see that the role and importance of accounting policies in an organization's 
accounting is high. It is natural that in the period of structural changes in the economy of any country, it is natural to adopt regulations that are temporarily in force or relate only to a particular industry or sector. The existence of problems in business entities, such as the organization of their activities under the new procedures and standards, or the adaptation of existing management methods to it, indicates the urgency of developing accounting policies. In addition, as a result of systemic reforms in recent years to develop the provision of non-governmental educational services in the country, there has been a sharp increase in the number of businesses providing non-governmental educational services. According to the State Inspectorate for Quality Control in Education under the Cabinet of Ministers of the Republic of Uzbekistan, as of November 2020, the number of businesses engaged in the provision of non-state educational services in the country is 2,580 [http://ntm.tdi.uz/?mod=ntmidx].

Current regulations provide for the development and approval of accounting policies "for the purpose of organizing accounting". The new version of the Tax Code, which came into force on January 1 , 2020 [2], also introduced the concept of "accounting policy for tax purposes".

As a result of the ongoing reforms in our country, the volume of services provided in the main types of economic activity, in the field of education is also growing from year to year. In 2015, it amounted to 2681.4 billion soums, while in 2019 it will be 7164.9 billion soums. These data show that the volume of services in the field of education in 2019 increased by 9.4 times compared to 2010 . One of the factors influencing this indicator is the fact that during this period, many nongovernmental educational entities have launched service activities in the field of education. Along with the growing number of legal entities engaged in this activity, issues related to the organization of accounting in these organizations are also becoming increasingly important.

\section{THE MAIN FINDINGS AND RESULTS}

In order to organize the correct and efficient operation of accounting, first of all, it is necessary to develop accounting policies in business entities. In accordance with the National Accounting Standard No. 1 "Accounting Policy and Financial Reporting" [4] (registered by the Ministry of Justice of the Republic of Uzbekistan on August 14, 1998, No. 474), the accounting policy means that the head of the business entity is responsible for accounting and financial reporting, the methods they use, their principles and foundations together. Methods of accounting include methods of grouping it and assessing the facts of economic activity, payment of the value of assets, methods of organization of document flow, inventory, methods of applying accounting records, system of accounting registers, information processing and other relevant methods, techniques and techniques. The accounting policy of the business entity is formed by the head of the entity on the basis of this NAS (National Accounting Standards) so that the financial performance of the business entity presented in the financial statements for different years is comparable.

According to Article 11 of the Law of the Republic of Uzbekistan "On Accounting” [1], 
the organization of accounting and reporting is carried out by the head of the accounting entity. In this process, the head of the accounting entity has the following rights:

$>$ Organization of the accounting service under the leadership of the head of the accounting service or use of the services of the accountant hired on a contractual basis;

$>$ Assignment of accounting to a specialized organization (audit organizations, tax advisory organizations and other organizations whose charter provides for the provision of accounting services) on a contractual basis;

$>$ Independent accounting.

Regardless of which of the above is chosen by the organization to organize and maintain its accounting records, it is important to formulate an accounting policy. Accounting policy should take into account the organizational and legal form of ownership, type of activity, system of taxation and a number of other factors.

Legal entities providing non-governmental educational services should also develop accounting policies as independent subjects of accounting. They should pay attention to the conditions of economic activity and the specifics of the activity in the development of accounting policies. This is because, in addition to the generally accepted normative and legal documents related to the organization and maintenance of accounting for each type of activity, there may be internal normative documents and methodological recommendations of the industry. It is also important to take into account the specifics of any activity, not only in the process of managing the organization, but also in the formation of data for internal and external users.

We can divide data users into the following groups in business entities providing non-state educational services (Figure 1).

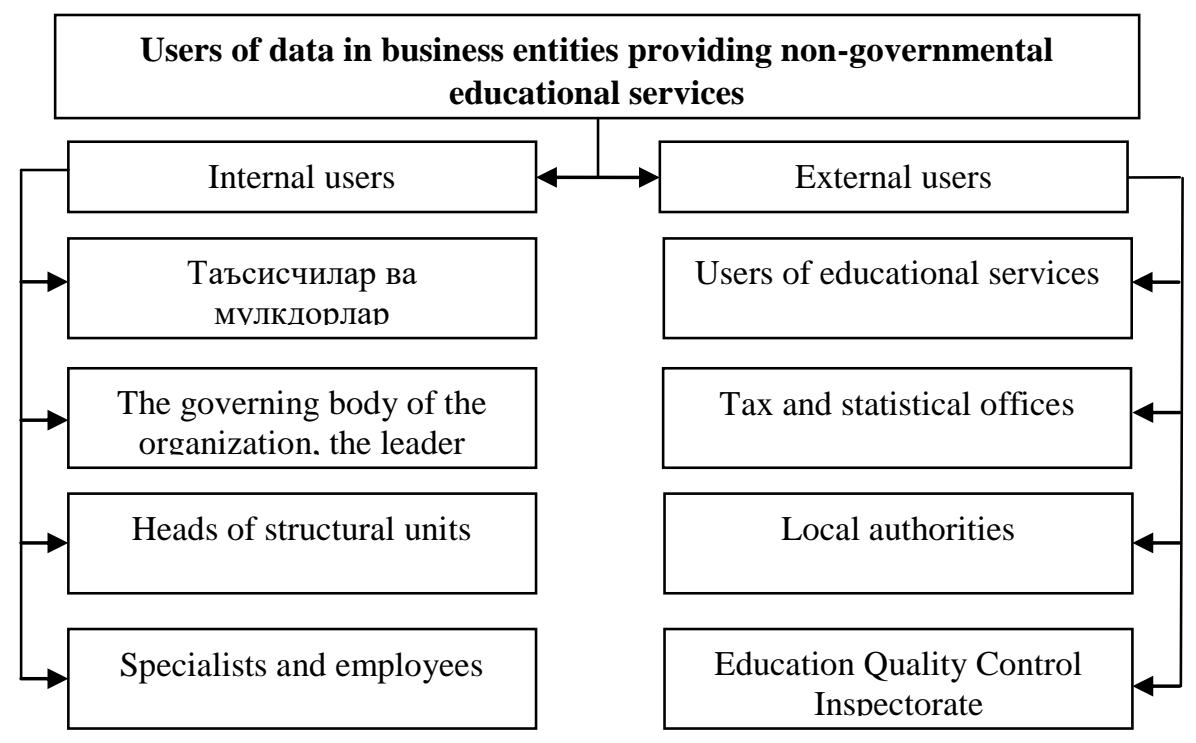

Figure 1. Users of data in business entities providing non-governmental educational services (compiled by the author) 
The diversity of users of the data generated in the accounting of business entities providing non-state educational services requires the invention of certain tools for these users to form this data obtained from the accounting of the business entity. Of course, in this process, the accounting policy of the organization is a tool that determines the order of formation of this data, and it helps to generate data for accounting in a timely and complete manner for different accounting systems.

According to the current regulations, the accounting policy of the business entity is formed by the head of the business entity so that the financial performance of the business entity presented in the financial statements for different years is comparable. This aspect of accounting policy has also been interpreted many times by world economists and various conclusions have been drawn.

In particular, according to $\mathrm{S}$. Adebayo, "accounting policies are important in interpreting the information presented in the financial statements. This is because accounting standards allow the use of alternative options for reporting the same economic indicators. Therefore, if the accounting policy does not clearly specify the procedure and limits for the presentation of indicators in the financial statements, users of financial reporting data will not be able to compare the same economic indicator with the same indicator of another organization" [6, p. 192].

In addition to the head and chief accountant, the services of other departments and specialists are used in the development of accounting policies in legal entities providing non-governmental educational services. For example, Deputy Head of Academic Affairs, Deputy Head of Scientific Affairs, Head of Library, Economists, and others.

Economists have proposed the following main stages of accounting policy development:

1. Development of an accounting work plan;

2. Full reflection of accounting in the work plan;

3. Development of the form of working reporting documents;

4. Document management and documentation processes;

5. Methods of valuation of assets and liabilities;

6. Inventory of assets and liabilities.

Using these steps, it covered some aspects of the activities of legal entities providing nongovernmental education services. It is not enough to develop an accounting policy that fully answers the questions that may arise during the accounting process.

\section{RESULTS}

In our opinion, the process of developing accounting policies in legal entities providing non-governmental educational services can be divided into the following stages:

Step 1. At this stage, the analysis of the current state of the organization's accounting, the study of regulatory documents on the organization and maintenance of accounting. At this stage, the study of the internal regulations and methodological guidelines for the accounting of the industry, which reflect the specifics of the education system, will also be carried out. 
Step 2. At this stage, the organizational structure of the educational institution, the structure of internal reports, the content and structure of data for external users are developed. Some of the external users of the data; In particular, given that tax and statistical offices have reporting and accounting forms that are common to all business entities, special attention should be paid to the fact that the data for these reporting and accounting forms should be based on generally accepted regulations.
Step 3. This stage is the main stage of accounting policy development. The accounting policy development process can be conditionally summarized in 3 aspects: organizational, technical and methodological aspects. The organizational aspect of the accounting policy reflects the composition of the staff involved in the development of the accounting policy and the order of data exchange (Figure 2).

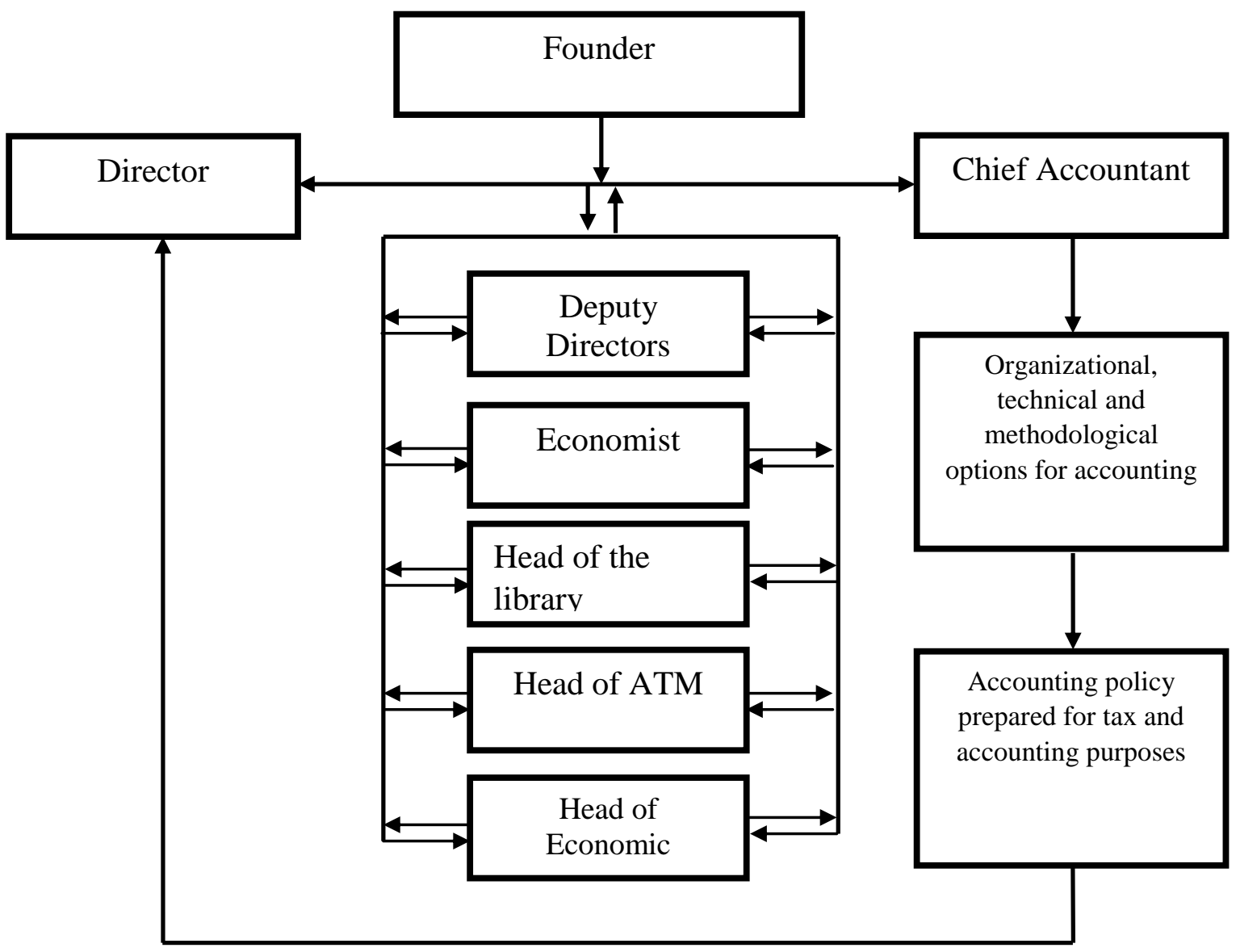

Figure 2. Staffing and information sharing procedures involved in the accounting policy development process (Compiled by the author)

Technically, the participants in the accounting process, the means of accounting, the mechanisms of data generation and processing 
are identified. In the methodological aspect of the accounting policy, the objects of accounting, their evaluation, timing and procedures for recognition are reflected, and the final draft of the accounting policy is prepared. The technical and methodological aspects of the accounting policy are shown in Figure 3.

\section{ACCOUNTING POLICY}

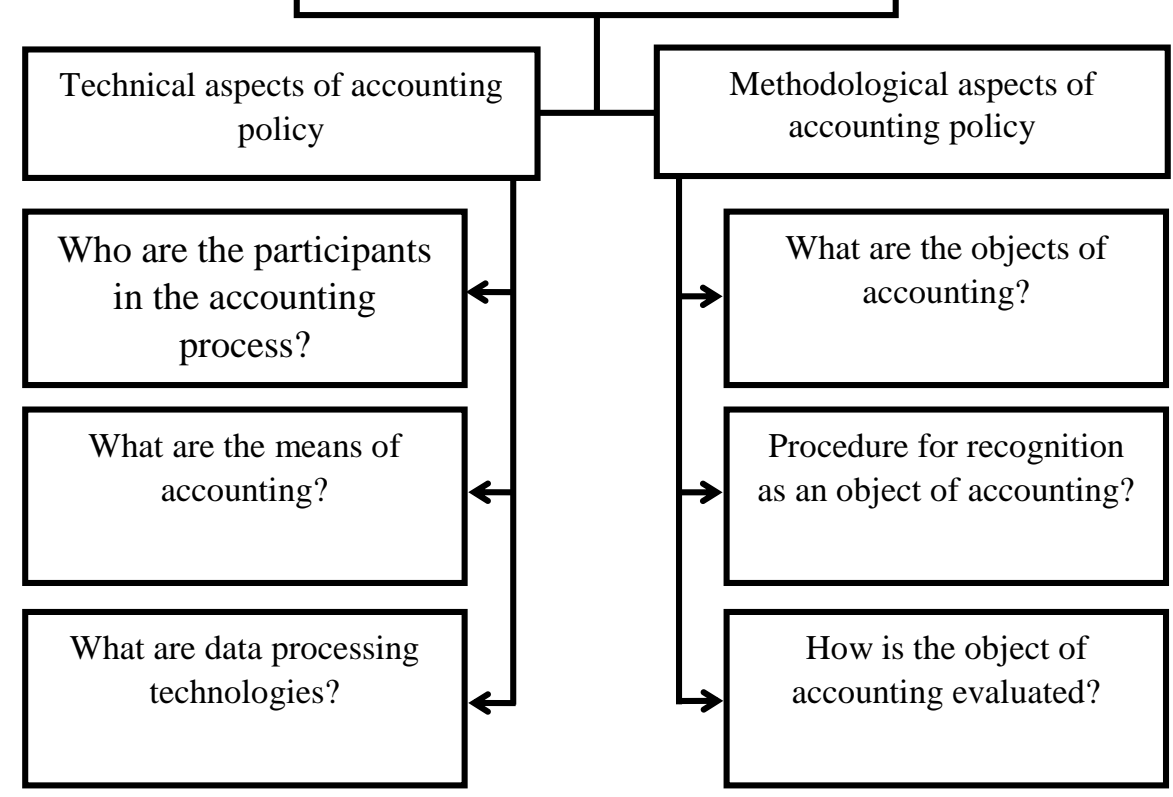

Figure 3. Technical and methodological aspects of accounting policy (Compiled by the author)

Step 4. The draft accounting policy prepared at this stage is finally discussed with the heads of departments and approved by the order of the head of the organization.

Each of the above conditional steps requires the implementation of certain tasks for the development of accounting policies in business entities providing non-state educational services. The most timeconsuming and labor-intensive of these stages is Stage 3. At this stage, the accounting method that answers all the questions is selected by the business entities (founders, owners) and their managers to meet the requirements of the accounting policy.
Adoption of one of the methods of accounting in the framework of existing regulations as a whole, without any changes

and additions, of course, may not allow businesses providing non-state educational services to generate complete data for users of accounting data. The method of accounting can be made arbitrary changes and additions, which do not contradict the existing regulations, taking into account the specifics of the activity.

It is also necessary to study the activities of public education services in the development of business entities providing nongovernmental education services and the 
organization of accounting in them. Public educational institutions have a practice of forming extra-budgetary funds for the development of educational services based on the requirements of a market economy. These aspects have been studied in A. Ostonokulov's scientific researches. "The formation of extrabudgetary funds in budget organizations will simultaneously provide additional funding for the social sphere and a significant reduction in the state budget for these purposes. There are special features of the account of educational services in the formation of extrabudgetary funds" [7].

In our opinion, the above definitions and aspects do not fully disclose the concept of accounting policy. This is due to the fact that the accounting policy of each business entity has a number of factors, such as the type of activity, organizational and legal form of ownership, regulatory documents related to the activity, seasonality of activities and others; in our view, it is not possible to formulate an accounting policy without fully taking into account the impact of such factors.

As a result of my research, we believe that the proposed 4-step approach to the development of accounting policies will be effective in the development of accounting policies in business entities that provide nongovernmental educational services. Because this 4-step method, which allows you to predict the sequence of work to be done at each stage, the responsible and the expected outcome, combining all the definitions and approaches to the above accounting policy on a single basis, creates a single tool.

\section{CONCLUSION}

When organizing accounting in business entities providing non-governmental educational services, it is necessary to take into account the amount and type of information used by users of accounting data and management decisions, as well as other criteria. In particular, the development of the chart of accounts used in accounting, the organization of accounting registers, the definition of data processing technologies and methods, the definition of primary accounting documents, accounting registers and internal reporting forms, the development of document exchange procedures, compiling a list of officials to whom power of attorney is issued, forming a list of accountants, determining the forms and terms of settlements with them, determining the volume and forms of accounting, developing conclusions on the choice of taxation system, determining procedures for accounting for income and expenses and other criteria should. On the basis of these criteria, business entities providing non-state educational services can create an account in the form that is most optimal for conducting business activities.Proper and accurate grouping of accounting items is also important in the proper organization of accounting. In particular, the effective organization of the accounting service can be achieved through the correct distribution of accounts among fixed assets, intangible assets, inventories, cash investments and other objects of accounting in the accounting process.

Another factor that should be taken into account in the correct and effective organization of accounting in business entities engaged in the provision of non-governmental educational services is the automated accounting systems used in the process of this 
service. At present, various software products for accounting automation in the country; in particular, 1S, 1Uz, BEM and other software products are available. The use of these programs can further increase the ability to obtain and analyze information from accounting, resulting in an increase in the financial and economic performance of the organization through effective management decisions.

\section{REFERENCES}

1. Law of the Republic of Uzbekistan "On Accounting". (Law of the Republic of Uzbekistan No. 404 of April 13, 2016). https://lex.uz/docs/2931253 (Ўзбекистон Республикасининг "Бухгалтерия хисоби тўғрисида"ги Қонуни. (2016 йил 13 апрель, $\quad$ ЎРқ-404-Сон). https://lex.uz/docs/2931253)

2. Tax Code of the Republic of Uzbekistan. (National Database of Legislation, 31.12.2019, No. 02/19 / SK / 4256). https://lex.uz/docs/4674902 (Ўзбекистон Республикасининг Солиқ кодекси. (Қонун хужжатлари маълумотлари миллий базаси, 31.12.2019 й., 02/19/(K/4256-Сон).

https://lex.uz/docs/4674902)

3. International Financial Reporting Standards-8 (IAS-8) “Accounting Policies, Changes and Errors in Accounting Evaluation".

https://finotchet.ru/articles/135/ (MXXXC-8 (IAS-8) "Хисоб сиёсати, бухгалтерия бахолашдаги ўзгаришлар ва хатолар". https://finotchet.ru/articles/135/)

4. National Accounting Standard No. 1, Accounting Policy and Financial Reporting. (Registered by the Ministry of Justice of the Republic of Uzbekistan on
August 14, 1998, No. 474).("Хисоб сиёсати ва молиявий хисобот" номли 1сонли бухгалтерия хисобининг миллий стандарти. (ЎзР АВ томонидан 1998 йил 14 августда 474-сон билан давлат рўйхатидан ўтказилган).)

5. Kurbonov Z.N. Scientific article "Theoretical issues of formation of accounting policies for tax purposes". Electronic scientific journal "Finance and Banking". 4/2019, 71-78. http://journal.bfa.uz/maqola/Maqola_4_s on_2019.pdf (Қурбонов 3.Н. “Солиққа тортиш мақсадидаги хисоб сиёсатини шакллантиришнинг назарий масалалари” илмий мақола. “Молия ва банк иши" электрон илмий журнал. 4/2019-сон, 71-78. http://journal.bfa.uz/maqola/Maqola_4_s on_2019.pdf)

6. Sunday Adebayo Alayemi. "Choice of Accounting Policy: Effects on Analysis and Interpretation of Financial Statements". American Journal of Economics, Finance and Management. Vol. 1, No. 3, 2015, pp. 190-194.

https://pdfs.semanticscholar.org/5403/48 gf4146f422582adefb1192ccod11752147.pdf

7. Ostonokulov Azamat Abdukarimovich. Budget Organizations Formation and Improving Accounting for Out-of Budget Budgets. International Journal of Advanced Science and Technology Vol. 29, No. 8s, (2020), pp. 11-16. ISSN: 20054238 IJAST Copyright 2020 SERSC. http://sersc.org/journals/index.php/IJAST/ article/download/10409/5603/.

8. http://www.lex.uz/docs/828581.

9. http://www.tdi.uz.

10. http://www.stat.uz. 